\title{
“MOVEMENT-MIRRORING” ARM EXOSKELETON IN REHABILITATION
}

\author{
A.A. Petrov1, alex_petrov_2@mail.ru, ORCID: 0000-0001-5072-2587, \\ A.S. Smirnov', 2231034@mail.ru, ORCID: 0000-0002-9529-638X, \\ V.V. Epishev', epishev74@mail.ru, ORCID: 0000-0002-7284-7388, \\ A.V. Shevtsov', sportmedi@mail.ru, ORCID: 0000-0002-9878-3378 \\ ${ }^{1}$ South Ural State University, Chelyabinsk, Russian Federation, \\ ${ }^{2}$ National State University of Physical Culture, Sport and Health named after P.F. Lesgafta, \\ St. Petersburg, Russian Federation
}

\begin{abstract}
Aim. The aim of this article is to develop the prototype of arm exoskeleton for the treatment of upper limb movement activity after intracerebral hemorrhage or heart attack. Materials and methods. "Movement-mirroring" function was introduced with the help of the manipulating device consisting of the device for wireless data transfer, Arduino controller, exoskeleton servomotors, 3 accelerometers GY-85 and software, which detects angles. Results. We developed the prototype of the rehabilitation device, which was tested by 6 volunteers. Arduino controller allowed us to reduce the time needed for servomotor response up to $400 \mathrm{msec}$. Conclusion. If only one arm is affected as a result of hemiparesis or hemiplegia, then the rehabilitation therapy can be conducted in accordance with the program stated or by copying the movements of a healthy limb by means of 'movement-mirroring' function.
\end{abstract}

Keywords: exoskeleton, movement, rehabilitation.

\section{Introduction}

In modern medical practice the recovery of impaired limb function is often performed with the help of CPM machines (Continuous Passive Motion) - power-driven devices that allow the selection of angle of the limb flexion-extension in isotonic and isometric modes with controlled speed and range of motion [13, 17, 22]. Robotassisted mechanical treatment reduces the time needed for recovery of the range of motion in isolated joint, tissue regeneration, and edema alleviation. Such treatment also decreases the incidence of adhesions and joint contractures $[1,8$, $15,21,23,26,27]$. Another benefit of CPM therapy is that the patient may start exercising as early as in 24 hours after brain hemorrhage episode, which prevents complications associated with prolonged immobility, such as contractures and muscle atrophy, thrombosis and thromboembolism etc. [24, 25, 26].

In order to improve the effectiveness of posthemorrhage rehabilitation process, the principle of mirror therapy is used: the patient sits at the table with his arms stretched along the table; on the table there is a mirror placed in such a way that the patient can see the reflection of his/her intact arm meanwhile his/her affected arm is behind the mirror $[4,12,19]$. The patient tries to rise up both arms, but, due to brain damage, the affected arm does not move at all, or its movement is restricted. However, thanks to the mirror, the patient is unable to see it and believes his/her affected arm to be intact and move freely. Thus, damaged regions of the motor cortex are stimulated to find new neural connections, which accelerates the recovery process $[3,9]$.

The modern technique of mirror therapy is the following: the manipulating device put on the intact arm transfers the signal to servos of exoskeleton that copies the movements of the manipulating device. The manipulating device allows the therapist or the patient him/herself to conduct rehabilitative treatment remotely or at home $[10,11]$.

The aim of our research was to design a prototype robot-assisted "movement-mirroring" machine with manipulating device that is put on the intact arm and "reflects" its movements on the exoskeleton servos to recover motor function of the affected upper limb.

\section{Materials and methods}

When we started working on the prototype of the robot-assisted system we had to fulfil several related tasks and analyse the ways of rehabilitation $[2,6]$. We intended to minimize the range of potential problems for the patient, so we chose 


\section{Восстановительная и спортивная медицина}

to make the device compact ( $5 \mathrm{~kg}$ max, working dimensions limited to $70 \times 30 \times 20 \mathrm{~cm} \max$ ), affordable ( $1000 € \max )$, and available.

It is known that the sooner rehabilitation starts, the more effective the recovery process is. The device should resemble regular household items, be smooth to the touch, be visually acceptable, and not provoke mental discomfort associated with movements of the motors. The length of device should be approximately equal to the average arm length of an adult. The general layout of the device is shown in Fig. 1.

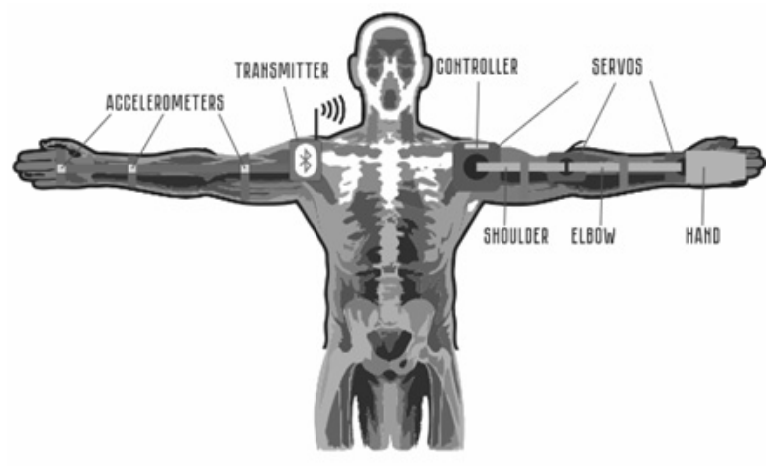

Fig. 1. General layout of "movement-mirroring" arm exoskeleton

\subsection{General Layout and Principles}

Servos were attached to the rectangular acrylic glass (plexiglass) plate $70 \mathrm{~cm}$ long and $25 \mathrm{~cm}$ wide. For softness the plate was covered with polyester wadding and fabric.

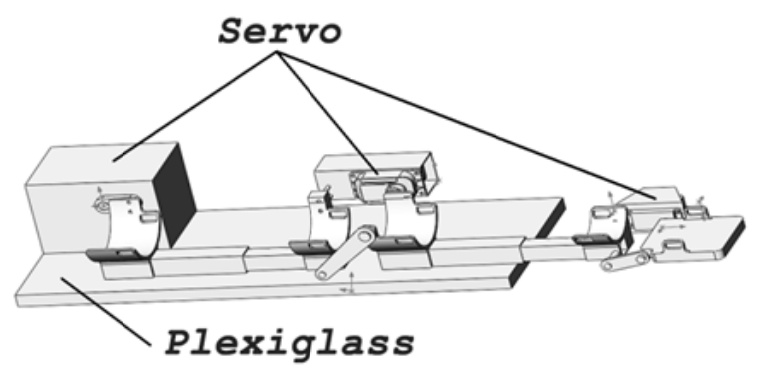

Fig. 2. Exoskeleton sketch

Servos were chosen for their ability to hold the weight at the preset angle [14]. For rehabilitation of three joints at once (elbow, shoulder, and wrist joints) we chose the following servos: Torxis i00800 High Torque Servo responsible for shoulder joint actions; Xq-S5650 servo responsible for elbow joint actions; and Savox sv1272sg servo responsible for wrist joint actions. We used SolidWorks software to create a 3D model of the arm exoskeleton where Torxis servo was located on the acrylic glass plate and supports the skele- ton frame of elbow and wrist joints together with servos (Fig. 2).

Ideally, mirror therapy technique requires that the intact and affected arms should move exactly in the same manner. As the servos able to hold the weight exactly in the pre-set position were chosen for the affected arm, it was rational to use accelerometers for the intact arm because they were able to locate the exact position at the given moment of time. We used 3 self-calibrating chips GY-85 to locate the positions of shoulder, elbow, and wrist joints.

The controller responsible for functioning of exoskeleton servos was ARDUINO UNO R2. The exoskeleton was powered with Inwin $300 \mathrm{w}$ power supply without overload protection. To create operating voltage for elbow and wrist joints we used down-converter for ARDUINO DC-DC using LM2596S microcircuit with input voltage of $12 \mathrm{~V}$ and output voltage of $7.2 \mathrm{~V}$ for each servo. The aluminium radiator was used to reject the heat which could be produced at onload position holding. Bluetooth receiver connected to adapter was chosen from Arduino developer set (HC-04).

\subsection{Procedure}

We conducted a series of experiments to assess the exoskeleton performance. Healthy volunteers were seated with their relaxed left arm in the exoskeleton meanwhile the laboratory technician was standing 1 meter apart and controlling the exoskeleton using the manipulating device (Fig. 3).

Test protocol included 10 slow repetitions of vertical movements: in shoulder joint with $0 . . .90^{\circ}$ amplitude (30-second pause), in elbow joint with $0 \ldots 120^{\circ}$ amplitude (30-second pause), in wrist joint $-30 \ldots+30^{\circ}$ (30-second pause). The next test involved 10 repetitions of the following succession of movements: shoulder joint raise by $60 \ldots 70^{\circ}$, elbow joint bending by $70 \ldots 90^{\circ}$ and wrist joint bending by $20 \ldots 30^{\circ}$ (60-second pause). The experiments involved 6 volunteers in total; average experiment session time was 8 minutes.

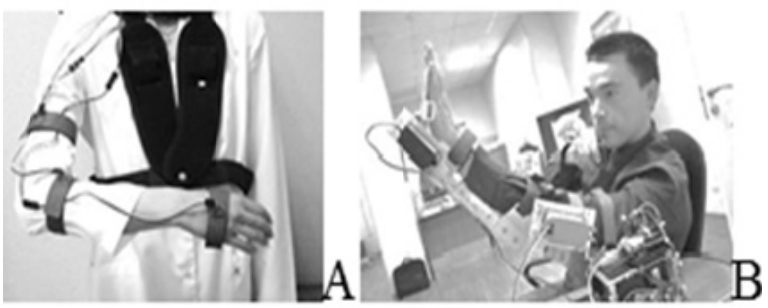

Fig. 3. The experiment procedure 


\section{Results}

\subsection{Servo Feedback Adjustment}

The construction features of the chosen servos do not include feedback, i.e. the controller does not receive the information that the servo has shifted to the required angle. Potentiometers of the servo were soldered with wires further connected to the controller for the current angle positioning. After doing this we were able to know the moment when the arm movement would be painful for the potential patient. For example, Fig. 4 presents the angle position chart for exoskeleton elbow frame. The controller sent the signal to the servo to shift the elbow frame by an angle of 50 degrees in 6 seconds. Having received the signal the servo started uniform velocity motion by the set angle. From $3.5 \mathrm{sec}$ it may be seen that the speed started to drop, and the controller decided to stop the elbow frame motion.

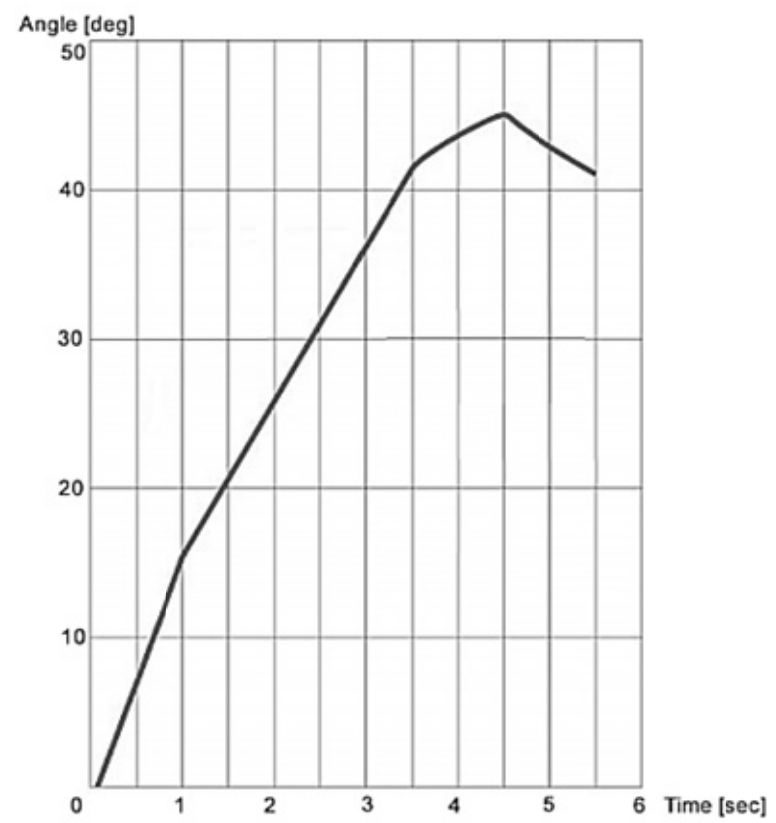

Fig. 4. Principle of servo functioning with adjusted feedback (servo stop at non-uniform motion)

\subsection{Accelerometer GY-85 angle detection}

To transfer output data of the accelerometer to degrees we used Open Source library Razor AHRS. We assembled the test stand (Fig. 5) including ARDUINO UNO R3 controller, 9V battery, accelerometer GY-85 and Xq-S5650 servo to test functioning and signal lag between accelerometer and servo.

Synchronization of vertical movements of accelerometer and servo was one of the main tasks for "movement mirroring" implementation. When accelerometer moves vertically servo should shift by the needed degree. To check it we disassembled the servo, soldered the wires to the potentiometer and connected them to Arduino controller. Fig. 6 presents the plot of angle shift versus time for accelerometer and servo. Maximum signal lag time between them was $400 \mathrm{~ms}$, maximum error was $2.6 \mathrm{deg}$. and occurred during rapid displacement of the accelerometer.

The next step was to construct the manipulating device prototype (Fig. 7) including CubieBoard controller, APC M10BK-EC.10000mAh battery, three accelerometers GY-85 attached on the belts and controller-powered, and USBBluetooth transmitter.

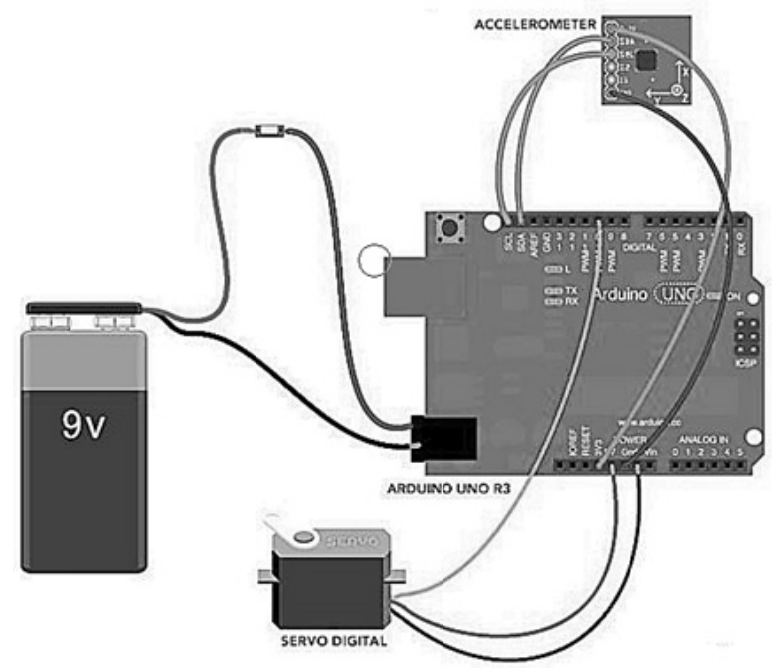

Fig. 5. Test stand for accelerometer positioning in degrees

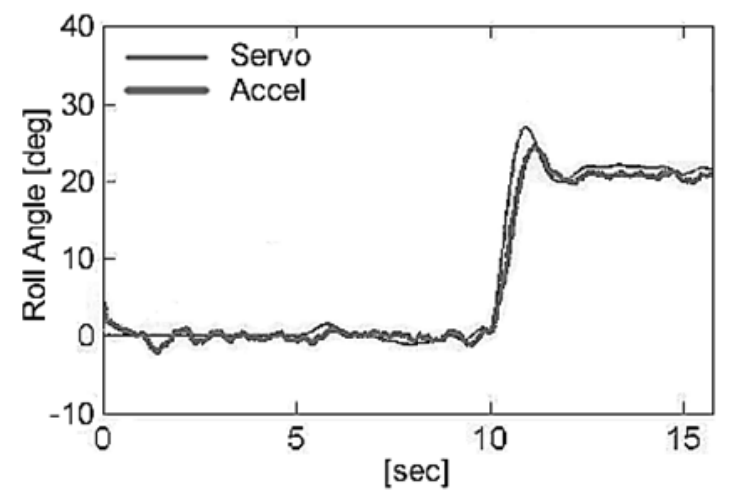

Fig. 6. Lag in signal transmission

between accelerometer and servo potentiometer

Then we assembled the exoskeleton consisting of servos, frame with arm supporting clamps and locks (Fig. 8). The frame is made of two square aluminium pipes $40 \times 40$ and $35 \times 35 \mathrm{~mm}$ in diameter for adjustment of shoulder and forearm length. For arm position support in the exoskeleton we made 4 semi-circular clamps of ABS plastic using 3D printer. ARDUINO UNO R3 controller is located on Torxis i00800 servo. Servo power management boards were attached on each 


\section{Восстановительная и спортивная медицина}

side of the construction for space saving purpose. Input voltage is $12 \mathrm{~V}$ for Torxis servo (shoulder joint), and 7.2 V for Xq-S5650 (elbow joint) and K-Power DMM300 (wrist joint) servos.

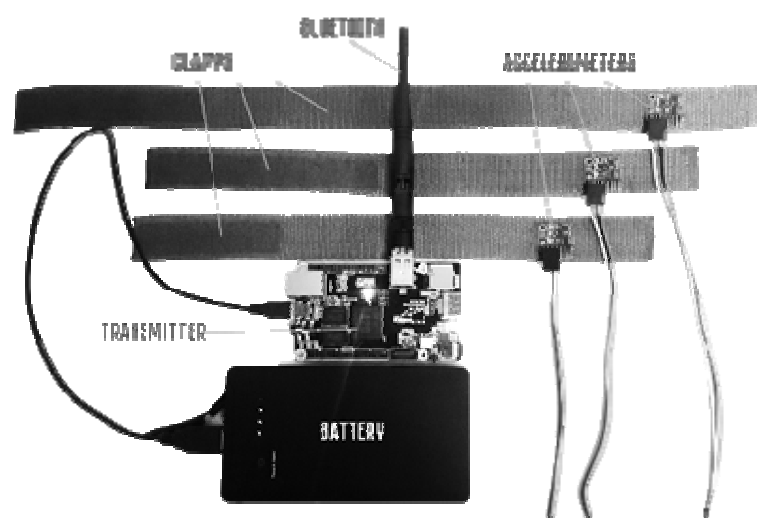

Fig. 7. Manipulating device prototype

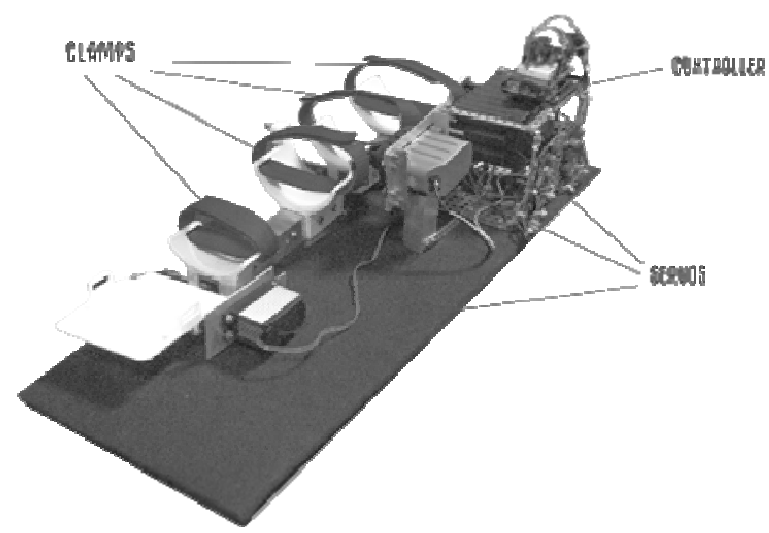

Fig. 8. "Movement-mirroring" arm exoskeleton prototype

\section{Discussion}

\subsection{Performance evaluation}

We evaluated the robot-assisted system performance using the following criteria:

Lag in signal transmission from accelerometers to servos;

As seen from Table 1, average lag time in the working prototype, in contrast with the test item, is over its former maximum values. However, we believe such lag to be insufficient as there are no visual differences in movements of the manipulating device and the accelerometer.

Table 1

Signal delay time

\begin{tabular}{|c|l|c|}
\hline № & \multicolumn{1}{|c|}{ Servo } & Lag, ms \\
\hline 1 & Shoulder & $490.5 \pm 32.1$ \\
\hline 2 & Elbow & $410.2 \pm 46.8$ \\
\hline 3 & Wrist & $450.8 \pm 27.3$ \\
\hline
\end{tabular}

Voltage consumption for different arm weights.
As seen from Table 2, the voltage converter using ARDUINO DC-DC LM2596S microcircuit is not suitable for our task and, thus, should be replaced with the more effective one $[5,20]$.

Table 2

Voltage consumption

\begin{tabular}{|c|c|c|}
\hline № & Arm weight, kg & $\begin{array}{c}\text { Output voltage } \\
\text { in LM2596S, V }\end{array}$ \\
\hline 1 & 4.1 & 5.9 \\
\hline 2 & 2.7 & 7.0 \\
\hline 3 & 4.3 & 5.6 \\
\hline 4 & 3.3 & 6.5 \\
\hline 5 & 3.1 & 6.8 \\
\hline 6 & 3.7 & 6.2 \\
\hline
\end{tabular}

Besides, the drawback discovered in the construction is the apparent vibration that starts at increasing load in elbow joint. However, the mechanical stability of the whole system will be improved if the exoskeleton construction includes stabilizing elements.

\subsection{Limitations and further research}

One of the main objectives of our research was to create the device that would be financially affordable for most of patients. Thus, the choice of materials and elements for the designed unit was limited.

The experiments were conducted on healthy volunteers in accordance with the approval granted by the Ethical Committee of the University (№39, 04.05.2016). Further research will involve the experiments using the model simulating a patient with hemiplegia.

The series of tests for assessment of electrical safety of the device is being conducted now.

"Movement-mirroring" arm exoskeleton prototype for rehabilitation of patients with disordered motor functions (for example, after brain haemorrhage) has proved its good performance. Construction elements are affordable and readily available. We believe that structural rework of exoskeleton will start the new trend in robotassisted rehabilitation, available for in-home use in particular.

In future, in addition to construction defect eliminating, we are planning to add the remote control function using the remote control unit or via the Internet, so that the data could be analysed and transmitted to the treating doctor.

Acknowledgements

South Ural State University is grateful for financial support of the Ministry of Education and Science of the Russian Federation (grant No. 19.9733.2017/BP). 


\section{References}

1. Ball S.J, Brown I., Scott S. Medarm: A Rehabilitation Robot with 5dof at the Shoulder Complex. Zurich: IEEE, 1-6, 2007.

2. Beer R.F., Dewald J.P., Dawson M.L., Rymer W.Z. Target-Dependent Differences Between Free and Constrained Arm Movements in Chronic Hemiparesis. Exp. Brain Res, 2004, vol. 156, pp. 458-470. DOI: $10.1007 / \mathrm{s} 00221-$ 003-1807-8

3. Bernstein N. The Coordination and Regulation of Movement. London: Pergamon Press, 1967, $196 \mathrm{p}$.

4. Blank A., O’Malley M.K., Francisco G.E., Contreras-Vidal G.L. A Pre-Clinical Framework for Neural Control of a Therapeutic UpperLimb Exoskeleton. San Diego, CA: IEEE, 2013, pp. 1159-1162. DOI: 10.1109/NER.2013.6696144

5. Brackbill E.A., Mao Y., Agrawal S.K., Annapragada M., Dubey V.N. Dynamics and Control of a 4-dof Wearable Cable-Driven Upper Arm Exoskeleton. Kobe: IEEE, 2009, pp. 2300-2305. DOI: 10.1109/ROBOT.2009.5152545

6. Carignan C., Liszka M., Roderick S. Design of an Arm Exoskeleton with Scapula Motion for Shoulder Rehabilitation. Seattle, WA: IEEE, 2005, pp. 524-531. DOI: 10.1109/ICAR.2005. 1507459

7. Carignan C., Tang J., Roderick S., Naylor M. A Configuration-Space Approach to Controlling a Rehabilitation Arm Exoskeleton. Noordwijk: IEEE, 2007, pp. 179-187. DOI: 10.1109/ICORR.2007.4428425

8. Culmer P.R., Jackson A.E., Makower S.G., Cozens J.A., Levesley M.C., Mon-Williams M. et al. A Novel Robotic System for Quantifying Arm Kinematics and Kinetics: Description and Evaluation in Therapist-Assisted Passive Arm Movements Post-Stroke. J. Neurosci. Methods, 2011, vol. 197, pp. 259-269. DOI: 10.1016/j. jneumeth.2011.03.004

9. DeJong G., Smout J., Horn D., Gassaway J., Maulden A. Timing of Initiation of Rehabilitation After Stroke. Arch. Phys. Med. Rehabil., 2015, vol. 86, pp. 34-40.

10. Ellis M.D., Drogos J., Carmona C., Keller T., Dewald J.P. Neck Rotation Modulates Flexion Synergy Torques, Indicating an Ipsilateral Reticulospinal Source for Impairment in Stroke. J. Neurophysiol, 2012, vol. 108, pp. 3096-3104. DOI: $10.1152 /$ jn.01030.2011

11. Ellis M.D., Sukal T., DeMott T., Dewald J.P. Augmenting Clinical Evaluation of
Hemiparetic Arm Movement with a LaboratoryBased Quantitative Measurement of Kinematics as a Function of Limb Loading. Neurorehabil. Neural Repair, 2008, vol. 22, pp. 321-329. DOI: 10.1177/1545968307313509

12. Fink M., Prada C., Wu F., Cassereau D. Self-Focusing with Time-Reversal Mirror in Inhomogeneous Media. Proc. IEEE Ultrason. Symp., 1989, pp.681-686. DOI: 10.1109/ULTSYM.1989.67072

13. French A., Pehlivan U., O’Malley K. Current Trends in Robot-Assisted Upper-Limb Stroke Rehabilitation: Promoting Patient Engagement in Therapy. Curr Phys Med Rehabil Rep, 2014, vol. 2, pp. 184-195. DOI: 10.1007/s40141014-0056-z

14. Galinski D., Sapin J., Dehez B. Optimal Design of an Alignment-Free Two-Dof Rehabilitation Robot for the Shoulder Complex. 2013 IEEE International Conference on Rehabilitation Robotics (ICORR) (IEEE), 2013, pp. 1-7. DOI: 10.1109/ICORR.2013.6650502

15. Klamroth-Marganska V., Blanco J., Campen K., Curt A., Dietz V., Ettlin T. et al. ThreeDimensional, Task-Specific Robot Therapy of the Arm After Stroke: a Multicentre, Parallel-Group Randomised Trial. Lancet Neurol, 2014, vol. 13, pp. 159-166. DOI: 10.1016/S1474-4422(13)70305-3

16. Kwakkel G., Kollen B., Lindeman E. Understanding the Pattern of Functional Recovery after Stroke: Facts and Theories. Restor. Neurol. Neurosci., 2004, vol. 22, pp. 281-299.

17. Namdari S., Horneff J., Baldwin K., Keenan M. Muscle Releases to Improve Passive Motion and Relieve Pain in Patients with Spastic Hemiplegia and Elbow Flexion Contractures. J Shoulder Elbow Surg, 2012, vol. 21, pp. 1357-1362. DOI: 10.1016/j.jse.2011.09.029

18. Ramachandran V.S., Rogers-Ramachandran D., Cobb S. Touching the Phantom Limb. Nature, 1995, vol. 377, pp. 489-490. DOI: 10.1038/377489a0

19. Regenbrecht H.T., Franz E.A., McGregor G., Dixon B.G., Hoermann S. Be+yond the Looking Glass: Fooling the Brain with the Augmented Mirror Box. Presence, 2011, vol. 20, pp. 559-576. DOI: 10.1162/PRES_a_00082

20. Roby-Brami A., Jacobs S., Bennis N., Levin M.F. Hand Orientation for Grasping and Arm Joint Rotation Patterns in Healthy Subjects and Hemiparetic Stroke Patients. Brain Res, 2003, vol. 969, pp. 217-229. DOI: 10.1016/S0006-8993(03)02334-5 


\title{
Восстановительная и спортивная медицина
}

21. Salter R.B., Simmonds D.F., Malcolm B.W., Rumble E.J., MacMichael D., Clements N.D. The Biological Effect of Continuous Passive Motion on the Healing of Full-Thickness Defects in Articular Cartilage. An Experimental Investigation in the Rabbit. $J$ Bone Joint Surg Am, 1980, vol. 62, pp. 1232-1251. DOI: 10.2106/00004623-198062080-00002

22. Shawn W.O., Giori J. Continuous Passive Motion (CPM): Theory and Principles of Clinical Application. J Rehabil Res Dev, 2000, vol. 37, pp. 179-188.

23. Song Z., Guo S., Pang M., Zhang S., Xiao N., Gao B., et al. Implementation of Resistance Training Using an Upper-Limb Exoskeleton Rehabilitation Device for Elbow Joint. J. Med. Biol. Eng, 2014, vol. 34, pp. 188-196. DOI: $10.5405 /$ jmbe. 1337

24. Sukal-Moulton T., Krosschell K.J., Gaebler-Spira D.J., Dewald J.P. Motor Impairment Factors Related to Brain Injury Timing in Early Hemiparesis. Part I: Expression of Upper-Extremity Weakness. Neurorehabil Neural Repair, 2014, vol. 28, pp. 13-23. DOI: $10.1177 / 1545968313500564$

25. Ver C., Hofgart G., Menyhart L., Kardos L., Csiba L. Ankle-Foot Continuous Passive Motion Device for Mobilization of Acute Stroke Patients. OJTR, 2015, vol. 3, pp. 11-40. DOI: 10.4236/ojtr.2015.32004

26. Volpe B.T., Lynch D., Rykman-Berland A., Ferraro M., Galgano M., Hogan N. et al. Intensive Sensorimotor Arm Training Mediated by Therapist or Robot Improves Hemiparesis in Patients with Chronic Stroke. Neurorehabil. Neural Repair, 2008, vol. 22, pp. 305-310. DOI: $10.1177 / 1545968307311102$

27. Zhang L.Q., Park H.S., Ren Y. Developing an Intelligent Robotic Arm for Stroke Rehabilitation. IEEE 10th International Conference on Rehabilitation Robotics (IEEE), 2007, pp. 984-993. DOI: 10.1109/ICORR.2007.4428543

Received 10 June 2018

Удк 616-036.82/.85

DOI: $10.14529 / h s m 180311$

\section{ПРИМЕНЕНИЕ ЭКЗОСКЕЛЕТА РУКИ С ФУНКЦИЕЙ «ЗЕРКАЛЬНОГО ДВИЖЕНИЯ» В РЕАБИЛИТАЦИОННЫХ ЦЕЛЯХ}

\author{
А.А. Петров ${ }^{1}$, А.С. Смирнов ${ }^{1}$, В.В. Епишев ${ }^{1}$, А.В. Шевцов ${ }^{2}$ \\ ${ }^{1}$ Южно-Уральский государственный университет, г. Челябинск, Россия \\ ${ }^{2}$ Национальный государственный университет фризической культуры, \\ спорта и здоровья имени П.Ф. Лесгафрта, г. Санкт-Петербург, Россия
}

Цель. Разработать прототип экзоскелета руки, предназначенного для лечения проблем движения верхней конечности после кровоизлияния в мозг или инфаркта. Материалы и методы. Функция «зеркального движения» реализована с использованием манипуляционного устройства, включающего в себя три акселерометра GY-85, программное обеспечение, которое отслеживает углы перемещения, устройства для беспроводной передачи данных, контроллер Arduino и сервомоторы экзоскелета. Результаты. В ходе этого исследования был разработан прототип реабилитационного устройства. Устройство было протестировано на 6 добровольцах. Использование Arduino позволило сократить время отклика сервомоторов до 400 мс. Выводы. Если поражена только одна рука, в случае гемипареза / гемиплегии, то восстановительная терапия может проводиться в соответствии с указанной программой или путем копирования движений здоровой конечности путем «зеркального движения».

Ключевые слова: экзоскелет, движение, реабилитация. 
Петров Алексей Александрович, аспирант кафедры теории и методики физической культуры и спорта Института спорта, туризма и сервиса, Южно-Уральский государственный университет. 454080, г. Челябинск, проспект Ленина, 76. E-mail: alex_petrov_2@mail.ru, ORCID: 0000-0001-5072-2587.

Смирнов Алексей Сергеевич, руководитель информационного отдела Института спорта, туризма и сервиса, Южно-Уральский государственный университет. 454080, г. Челябинск, проспект Ленина, 76. E-mail: 2231034@mail.ru, ORCID: 0000-0002-9529-638X.

Епишев Виталий Викторович, кандидат биологических наук, доцент, доцент кафедры теории и методики физической культуры и спорта Института спорта, туризма и сервиса, ЮжноУральский государственный университет. 454080, г. Челябинск, проспект Ленина, 76. E-mail: epishev74@mail.ru, ORCID: 0000-0002-7284-7388.

Шевцов Анатолий Владимирович, доктор биологических наук, доцент, заведующий кафедрой физической реабилитации, Национальный государственный университет физической культуры, спорта и здоровья имени П.Ф. Лесгафта. 190121, г. Санкт-Петербург, ул. Декабристов, 35. E-mail: sportmedi@mail.ru, ORCID: 0000-0002-9878-3378.

Поступила в редакцию 10 июня 2018 г.

\section{ОБРАЗЕЦ ЦИТИРОВАНИЯ}

"Movement-Mirroring" Arm Exoskeleton in Rehabilitation / A.A. Petrov, A.S. Smirnov, V.V. Epishev, A.V. Shevtsov // Человек. Спорт. Медицина. - 2018. T. 18, № 3. - C. 113-119. DOI: 10.14529/hsm180311

\section{FOR CITATION}

Petrov A.A., Smirnov A.S., Epishev V.V., Shevtsov A.V. "Movement-Mirroring" Arm Exoskeleton in Rehabilitation. Human. Sport. Medicine, 2018, vol. 18, no. 3, pp. 113-119. DOI: 10.14529/hsm180311 